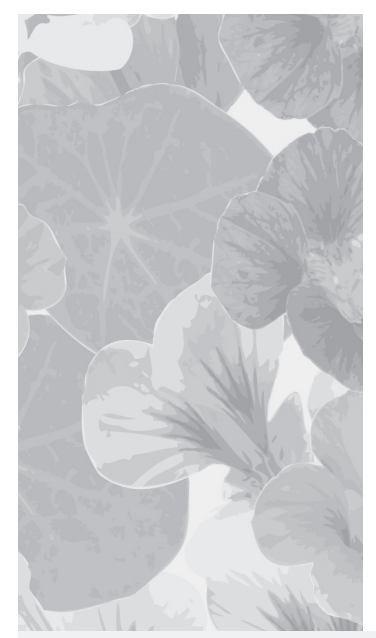

\title{
Motywy korzystania i poziom zadowolenia klientów Uzdrowiska Swoszowice
}

\author{
Motives for using and level of satisfaction among customers of the Swoszowice \\ health resort
}

Jadwiga Wojtanowska, Magdalena Niewęgłowska-Wilk, Tomasz Wilk

Zakład Dermatologii Doświadczalnej i Kosmetologii, Wydział Farmaceutyczny

Uniwersytet Jagielloński Collegium Medicum, Kraków

Estetol Med Kosmetol 2012; 2(1): 21-23

DOI: http://dx.doi.org/10.14320/EMK.2012.004

\section{Streszczenie}

Leżące na obrzeżach aglomeracji krakowskiej Uzdrowisko Swoszowice specjalizuje się w leczeniu chorób reumatycznych, neurologicznych, stanów pourazowych i pooperacyjnych narządów ruchu, a także chorób skóry. Cel: Zbadanie motywów korzystania z usług uzdrowiskowych oraz poziomu zadowolenia z tych ustug w grupie pacjentów odbywających turnus leczniczy w Swoszowicach. Materiaty i metody: Badania ankietowe 147 kuracjuszy w trakcie odbywania 21-dniowego turnusu leczniczego. Wyniki: Największą grupę korzystających z ustug uzdrowiskowych stanowili pacjenci ambulatoryjni (90 osób; 61,2\%) oraz osoby powyżej 60 roku życia (75 osób; 51,0\%). Jako główny motyw pobytu w uzdrowisku, 105 osób (71,4\%) wymieniło chęć poprawy stanu zdrowia, a najczęściej wymienianym głównym czynnikiem wyboru uzdrowiska była jakość opieki lekarskiej (60 osób; $40,8 \%$ ). Spośród dodatkowych usług podczas pobytu w uzdrowisku pacjenci najczęściej korzystali z zabiegów odnowy biologicznej (71 osób; 48,3\%). Większość kuracjuszy (81 osób; $55,1 \%$ ) zauważyła zdecydowaną poprawę zdrowia po odbyciu kuracji uzdrowiskowej. Wnioski: Większość klientów Uzdrowiska Swoszowice stanowią pacjenci ambulatoryjni, a głównym motywem odbycia leczenia jest chęć poprawy stanu zdrowia. Kuracjusze przebywający w uzdrowisku są zadowoleni z jakości świadczonych usług i większość z nich dostrzega poprawę stanu zdrowia.

Stowa kluczowe: Uzdrowisko Swoszowice, lecznictwo uzdrowiskowe, odnowa biologiczna, turystyka uzdrowiskowa

\begin{abstract}
The health resort Swoszowice is located at the edge of the urban agglomeration of Krakow and specialises in treating rheumatic and neurological diseases, post-traumatic and postoperative conditions of musculoskeletal system, as well as skin diseases. Aim: To study the motives for using the health resort's services and the level of satisfaction with the services of patients taking cure at Swoszowice. Materials and methods: Questionnaires administered to 147 health resort patients during their 21-day therapeutic stay. Results: Outpatients constituted the majority of the resort's services users ( 90 people, $61.2 \%$ ), as did people older than 60 years (75 people, $51.0 \%)$. As the main reason for staying at the health resort, 105 respondents $(71.4 \%)$ indicated on the wish to improve their health status. As the most important factor of choosing the health resort, the quality of medical care was named by 60 people (40.8\%). From among additional services available during their stay, most respondents (71 people, $48.3 \%$ ) have chosen spa treatments. The majority of respondents ( 81 people, $55.1 \%$ ) have noticed a significant health improvement after their stay. Conclusions: The majority of customers at the Swoszowice health resort are outpatients, for whom the main motive for the treatment is their wish of improving their health. They are satisfied with the quality of the services and the majority experiences an improvement in their health.
\end{abstract}

Keywords: health resort Swoszowice, spa treatment, biological regeneration, health resort tourism

Copyright $\odot 2012$ the Authors (text) and Radostaw Śpiewak (layout \& journal compilation). All rights reserved.

Pod pojęciem usług uzdrowiskowych rozumie się nie tylko usługi związane z lecznictwem uzdrowiskowym, ale także coraz bardziej popularną i modną turystyką uzdrowiskową. Obecnie uzdrowiska w Polsce to nie tylko ośrodki, w których oferuje się leczenie uzdrowiskowe, ale także centra wypoczynku, rekreacji oraz odnowy biologicznej. W dzisiejszych czasach zauważa się dynamiczny rozwój usług związanych z potrzebą regeneracji sił fizycznych, psychicznych i duchowych człowieka. Wynika to z coraz częstszego rozprzestrzeniania się chorób cywilizacyjnych XXI wieku, do których należą stres, przemęczenie, skutki zanieczyszczenia powietrza, itp. Dlatego też ważną rolę w zakresie poprawy zdrowia oraz profilaktyki zdrowotnej odgrywają uzdrowiska. Usługi w nich oferowane muszą speł- niać oczekiwania coraz bardziej wymagających kuracjuszy oraz turystów, chcących nie tylko polepszyć swój stan zdrowia, ale także zregenerować siły organizmu.

Lecznictwo uzdrowiskowe ma bardzo długą historię. Trudno określić kiedy ludzie zaczęli przyjeżdżać do miejsc, gdzie znajdowały się źródła wód mineralnych lub innych produktów uzdrowiskowych. Jedne z najstarszych miejscowości uzdrowiskowych, także te w Polsce, zaczęły rozwijać się około XII i XIII wieku. Były one zazwyczaj zlokalizowane wokół ciepłych źródeł. $\mathrm{Z}$ biegiem lat, liczba uzdrowisk zarówno w Polsce, jak i w Europie bardzo szybko rosła. Druga połowa XIX wieku była uważana za złotą erę lecznictwa uzdrowiskowego [4]. Wtedy też rozkwitały różne formy lecz- 
nictwa uzdrowiskowego, wśród których najpopularniejsze to klimatoterapia, talasoterapia i balneoterapia [5]. Balneoterapia jest zabiegiem wykorzystującym wody mineralne w kąpielach leczniczych [6]. W dzisiejszych czasach wykazuje ona duży wpływ na różne specjalności medyczne w Polsce, w szczególności stanowi uzupełnienie farmakoterapii. Ponadto, jest ona włączana do programu studiów medycznych i jest jedną z bardziej popularnych „podspecjalności” [4]. Uważana jest za jedną z bezpieczniejszych metod terapeutycznych [7]. Talasoterapia natomiast jest terapeutyczno-profilaktyczną formą leczenia opartą na starożytnych wierzeniach w naturalną moc uzdrawiania za pomocą leczniczych właściwości wody morskiej, alg, piasku i klimatu [5,7]. Uważana jest za alternatywną metodę poprawy zdrowia oraz terapię przeciwstarzeniową. Popularna jest głównie wśród turystów szukających relaksu, wyciszenia, a także ogólnej poprawy samopoczucia [5]. Klimatoterapia obejmuje alternatywne metody leczenia stosujące możliwości zasobów naturalnych, takich jak powietrze, temperatura, wilgotność, ciśnienie atmosferyczne i światło [7].

Warunki klimatyczne i rodzaj naturalnych surowców leczniczych są najważniejszymi czynnikami określającymi profil leczniczy (specjalizację) danego uzdrowiska. Znanymi i cenionymi walorami leczniczymi Uzdrowiska Swoszowice są jego wody mineralne, które wykorzystywane są do zabiegów balneoterapii, a także klimat odznaczający się doskonałymi właściwościami leczniczymi. Zarówno pozyskiwane na terenie Uzdrowiska Swoszowice wody mineralne, jak również sprzyjający klimat są cennymi surowcami w leczeniu schorzeń reumatologicznych, pourazowych i pooperacyjnych narządów ruchu, dermatologicznych (np. łuszczycy), neurologicznych, chorób dróg oddechowych, czy zatruć.

\section{Cel}

Celem pracy była ocena motywów korzystania i poziomu zadowolenia z usług uzdrowiskowych w grupie pacjentów Uzdrowiska Swoszowice. Badania miały na celu uzyskanie odpowiedzi na pytania o główne motywy pobytu w uzdrowisku, jakie czynniki wpływają na wybór uzdrowiska, z jakich usług pacjenci korzystali podczas pobytu w uzdrowisku i czy pobyt poprawił ich samopoczucie.

\section{Materiat i metody}

Badanie polegało na przeprowadzeniu ankiety wśród 147 kuracjuszy w wieku między 30 a 70 rokiem życia w trakcie odbywania 21-dniowego turnusu leczniczego. Udział w badaniu był w pełni dobrowolny. Anonimowa ankieta składała się z pięciu pytań o główne motywy wyboru pobytu w uzdrowisku, czynniki wpływające na wybór uzdrowiska, usługi z jakich pacjenci korzystali podczas pobytu, a także o poprawę stanu zdrowia na podstawie indywidualnej, subiektywnej oceny badanego.

\section{Wyniki}

Strukturę klientów korzystających z usług uzdrowiska Swoszowice przedstawia tabela 1 . Wszyscy respondenci mieli ponad 30 lat, największą grupę stanowiły osoby powyżej 60 roku życia (75 osób; 51,0\%); kuracjuszy w grupach wiekowych 50-59 lat i 40-49 lat było po 27 $(18,4 \%)$, najmniej było osób w wieku 30-39 lat (18 osób; 12,2\%). W badanej grupie większość stanowiły kobiety (114 osób; 77,6\%). Najważniejsze czynniki wyboru uzdrowiska Swoszowice podane przez respondentów przedstawia tabela 2 . W pytaniu o główne motywy pobytu w uzdrowisku, 105 osób $(71,4 \%)$ wskazało na chęć poprawy zdrowia, 18 osób (12,2\%) na chęć poprawy kondycji fizycznej i psychicznej, 12 osób $(8,2 \%)$ przebywało $\mathrm{w}$ uzdrowisku $\mathrm{w}$ ramach rekonwalescencji po chorobie, a kolejne 12 osób (8,2\%) zdecydowało się na odpoczynek i relaks w uzdrowisku. Spośród dodatkowych usług oferowanych w uzdrowisku, kuracjusze najczęściej korzystali z zabiegów odnowy biologicznej (71 osób; 48,3\%) oraz zorganizowanych ćwiczeń gimnastycznych (45 osób; 30,6\%). Niewielka grupa (31 osób; 21,1\%) korzystała z wycieczek rekreacyjno-turystycznych. Przechodząc do ogólnej oceny wpływu pobytu w Uzdrowisku Swoszowice na stan zdrowia oraz samopoczucie, większość kuracjuszy (81 osób; 55,1\%) deklarowała zdecydowaną poprawę stanu zdrowia po odbyciu kuracji uzdrowiskowej, a dalsze 45 osób (30,6\%) uważało, że pobyt w uzdrowisku raczej im pomógł. Sześciu respondentów $(4,1 \%)$ uznało, że kuracja raczej im nie pomogła, natomiast 15 pozostałych uczestników badania $(10,2 \%)$ nie potrafiło udzielić odpowiedzi na to pytanie.

Tabela 1. Struktura klientów korzystających z ustug Uzdrowiska Swoszowice

\begin{tabular}{l|l} 
Pacjenci ambulatoryjni & $61,2 \%$ \\
\hline Kuracjusze sanatoryjni & $18,4 \%$ \\
\hline Kuracjusze szpitalni & $14,3 \%$ \\
\hline Turyści & $4,1 \%$ \\
\hline $\begin{array}{l}\text { Osoby korzystające } \\
\text { z odnowy biologicznej }\end{array}$ & $2,0 \%$ \\
\hline
\end{tabular}

Tabela 2. Najważniejsze czynniki decydujące o wyborze Uzdrowiska Swoszowice

\begin{tabular}{l|l} 
Jakość opieki lekarskiej & $40,8 \%$ \\
\hline Jakość bazy zabiegowej i profesjonalizm personelu & $30,6 \%$ \\
\hline Miła atmosfera w kontaktach z personelem & $12,2 \%$ \\
\hline Odpowiednie towarzystwo & $10,2 \%$ \\
\hline Jakość bazy noclegowej i gastronomicznej & $4,1 \%$ \\
\hline Odpowiednia organizacja czasu wolnego & $2,1 \%$
\end{tabular}




\section{Dyskusja}

Lecznictwo uzdrowiskowe zajmuje się leczeniem, profilaktyką i rehabilitacją chorób przewlekłych, które stanowią obecnie największe wyzwanie zdrowia publicznego. Leczenie uzdrowiskowe ma na celu zdrowotne oddziaływanie zarówno ogólnoustrojowe, jak i miejscowe za pomocą bodźców naturalnych. Wymaga ono stosowania serii zabiegów, a efekty lecznicze nie występują natychmiast. Leczenie uzdrowiskowe zwiększa efektywność leczenia farmakologicznego, a w niektórych wypadkach pozwala na zredukowanie, czy wręcz odstawienie leków [1]. Obecnie obserwuje się duże zainteresowanie turystyką uzdrowiskową. Model ten, popularny do tej pory w Niemczech, Austrii, Włoszech, Francji, został przeniesiony również na krajowy rynek uzdrowiskowy. W Polsce są 43 uzdrowiska, w których chorzy mogą znaleźć fachową opiekę lekarską i pielęgniarską, czy też skorzystać z badań laboratoryjnych, jednocześnie odpoczywając w atrakcyjnych turystycznie ośrodkach górskich lub nadmorskich [1]. Współczesne uzdrowiska to już nie tylko szpitale uzdrowiskowe i sanatoria, ale również obiekty rekreacyjne i turystyczne [2]. Uzdrowisko Swoszowice położone jest w niewielkiej odległości od centrum Krakowa, co sprawia, że jest ono atrakcyjne dla turystów. W ostatnich latach uzdrowisko to stało się popularne w Polsce i Europie dzięki swym wodom mineralnym. Unikalną w skali europejskiej zaletą wody mineralnej Swoszowic jest to, iż jedynym czynnym biologicznie składnikiem są związki siarki, a nie zawiera ona bromu i jodu, które mogą wywierać efekty drażniące na organizm człowieka.

W lecznictwie uzdrowiskowym stosuje się programy lecznicze łączące kilka metod. Do najczęściej stosowanych należą: balneoterapia, klimatoterapia, kinezyterapia, psychoterapia, edukacja zdrowotna, farmakoterapia oraz dieta [1]. Ważną rolę odgrywają ponadto zabiegi fizykalne, w których skład wchodzą prądy niskiej i wysokiej częstotliwości, pulsujące pole magnetyczne, pole elektromagnetyczne wysokiej częstotliwości, ultradźwięki, aerozole, ciepło i zimno, promieniowanie podczerwone i nadfioletowe oraz niskoenergetyczne promieniowanie laserowe [3]. Zabiegi te są skuteczne, tanie, łatwo dostępne i, tak jak np. balneoterapia, przyjemne dla pacjentów [1]. Do niedawna głównymi bywalcami uzdrowisk były osoby starsze kierowane w ramach leczenia poszpitalnego, wymagające intensywnej kuracji oraz ścisłego nadzoru lekarsko-pielęgniarskiego [2]. Obecnie coraz więcej osób z własnej inicjatywy korzysta z zabiegów fizykalnych oraz medycyny naturalnej [3]. Stwarza to nadzieję, iż zestresowani szybkim tempem życia i zagrożeni chorobami cywilizacyjnymi ludzie coraz chętniej korzystać będą z możliwości przyrodolecznictwa, wybierając życie w harmonii z przyrodą, której walory będą dostarczać nie tylko wrażeń estetycznych, lecz także podtrzymywać siły i zdrowie [1].

\section{Wnioski}

Większość klientów Uzdrowiska Swoszowice stanowią pacjenci ambulatoryjni, a głównym motywem odbycia leczenia jest chęć poprawy stanu zdrowia. Kuracjusze przebywający w uzdrowisku są zadowoleni z jakości świadczonych usług i większość z nich odczuwa poprawę stanu zdrowia.

\section{Piśmiennictwo}

1. Helbin J, Kolarzyk E: Wykorzystanie walorów środowiska naturalnego w wspomaganiu leczenia farmakologicznego. Probl Higieny Epidemiol 2005; 86(1): 22-6.

2. Małecka B, Marcinkowski J: Współczesny model działalności uzdrowisk. Probl Higieny Epidemiol 2007; 88(1): $14-6$.

3. HelbinJ,KolarzykE: Czynnikifizykalnewykorzystywane w metodach lecznictwa uzdrowiskowego. Probl Higieny Epidemiol 2006; 87(3): 166-71.

4. Omulecki A, Nowak A, Zalewska A: Spa therapy in Poland. Clin Dermatol 1996; 14: 679-83.

5. Najebba R, Faiz RA: Spa therapy in dermatology. Indian J Dermatol 2011; 77(2): 128-34.

6. Matz H, Orion E, Wolf R: Balneotherapy in dermatology. Dermatol Ther 2003; 16: 132-40.

7. Kazandjieva J, Grozdev I, Darlenski R, Tsankov N: Climatotherapy of psoriasis. Clin Dermatol 2008; 26, 477-85.

\section{Finansowanie i konflikt interesów}

Przedstawione badania i przygotowanie niniejszej pracy zostało w całości sfinansowane $\mathrm{z}$ własnych środków autorów. Wszyscy autorzy deklarują niewystępowanie konfliktu interesów w odniesieniu do treści zawartych w niniejszej pracy.

\section{Adres do korespondencji}

mgr Jadwiga Wojtanowska

Zakład Dermatologii Doświadczalnej i Kosmetologii

Wydział Farmaceutyczny UJ

ul. Medyczna 9, 30-688 Kraków

Tel.: 1262058 30, fax: 126205645

E-mail: j.wojtanowska@uj.edu.pl

Data złożenia: 13.09.2011

Data akceptacji: 23.02 .2012

Data aktualizacji: 30.11 .2012 